\title{
Selective Immobilization of DNA and Antibody Probes on Electrode Arrays: Simultaneous Electrochemical Detection of DNA and Protein on a Single Platform
}

Jason C. Harper, Ronen Polsky, David R. Wheeler, Shawn M. Dirk, and Susan M. Brozik*

\section{Experimental}

Materials and Reagents

Synthetic oligonucleotides were produced by Integrated DNA Technologies, Inc. The following sequences were used:

Breast Cancer Probe (1)

5'-NH2-C6-GAC CTA GTC CTT CCA ACA GCT ATA AAC AGT-3'

Breast Cancer Target from BRCA1, (2)

5'-AAA GTG TTT TTC ATA AAC CCA TTA TCC AgG ACT GTT TAT AgC TGT TGG AAG GAC TAG GTC-3'

\author{
Breast Cancer Detection (3)
}

\section{5'-CCT GGA TAA TGG GTT TAT GAA AAA CAC TTT-Biotin-3'}

\section{Breast Cancer control - random DNA sequence (4) \\ 5'-TTC AgA AgC GAA TTC CAT ATA GCA CAA GTA ATC gGa CAC gTA CTA ATT ACA-3,}

Aqueous solutions were prepared with $18 \mathrm{M} \Omega$ water using a Barnstead Nanopure water purifier (Boston, MA). Recombinant human IL-12, along with respective capture antibodies and biotinlyated detection antibodies were purchased from eBioscience (San Diego, CA). Sodium phosphate monobasic, sodium phosphate dibasic, sodium carbonate,

sodium bicarbonate, ExtrAvidin ${ }^{\circledR}$ horseradish peroxidase (HRP), and $30 \% \mathrm{H}_{2} \mathrm{O}_{2}$ were purchased from Sigma (St. Louis, MO). Fluoroboric acid and tetrabutylammonium tetrafluoroborate $\left(\mathrm{Bu}_{4} \mathrm{NBF}_{4}\right)$ were purchased from Aldrich. Acetonitrile (ACN), 1-Ethyl3-[3-dimethylaminopropyl]carbodiimide hydrochloride (EDC), 4-aminobenzoic acid and 
N-hydroxysuccinimide (NHS) were purchased from Acros Organics (Beel, Belgium). Sulfuric acid, ethyl alcohol (95\% denatured), potassium chloride, saline sodium citrate (SSC) 20x solution, $\mathrm{pH} 7.0$, phosphate buffer saline (PBS) 10x solution, $\mathrm{pH} 7.4$, were purchased from Fischer Scientific (Pittsburgh, PA). 3,3',5,5'-Tetramethylbenzidine (TMB) conductivity solution and BSA Peroxidase stabilizer solution were received from BioFX laboratories, Inc. (Owings Mills, MD). All electrochemical measurements were performed on a PGZ 100 Voltalab potentiostat (Radiometer Analytical, Lyon, France) and were measured versus an $\mathrm{Ag} / \mathrm{AgCl}$ reference (3M, aqueous solutions) or a $\mathrm{Ag} / \mathrm{AgNO}_{3}$ reference $(10 \mathrm{mM}$, non-aqueous solutions) and a $\mathrm{Pt}$ counter electrode from Bioanalytical Systems (West Lafayette, IN). $500 \mu \mathrm{m}$ diameter gold disk arrayed electrodes, spaced $1.5 \mathrm{~mm}$ apart, were prepared via thermal evaporation of a $200 \AA \mathrm{Ti}$ adhesion layer followed by $2000 \AA \AA$ of Au onto a Pyrex wafer. Au electrodes were cleaned with piranha (5:3 conc. sulfuric acid: $\left.30 \% \mathrm{H}_{2} \mathrm{O}_{2}\right)$ solution for $5 \mathrm{~min}$, washed with nanopure water, and dried under a stream of nitrogen.

\section{Preparation of 4-carboxyphenyl diazonium tetrafluoroborate ${ }^{1}$}

4-aminobenzoic acid (2.74 g, $20.0 \mathrm{mmol})$ was dissolved in fluoroboric acid (48\%, $14.6 \mathrm{~g}, 80 \mathrm{mmol})$ and water $(20 \mathrm{~mL})$. The solution was heated until the aniline completely dissolved and was then cooled in an ice water bath. Sodium nitrite (1.46 g, $21.2 \mathrm{mmol})$ dissolved in water $(4 \mathrm{~mL})$ was added dropwise to the reaction mixture with stirring. The solution was allowed to warm to room temperature and was then concentrated via rotary evaporation to half the original volume. The solution was cooled in an ice bath, and the resultant white solid was collected and washed with cold ether to give $1.24 \mathrm{~g}(26 \%)$ of the desired diazonium salt.

\section{Diazonium Antibody Modification ${ }^{2}$}

$10 \mathrm{mg}$ of 4-carboxyphenyl diazonium tetrafluoroborate, $20.6 \mathrm{mg} \mathrm{EDC}$, and $11.5 \mathrm{mg}$ NHS were mixed in $1 \mathrm{~mL}$ of water for $10 \mathrm{~min}$. From this solution $10 \mu \mathrm{L}$ was added to $200 \mu \mathrm{L}$ of $500 \mu \mathrm{g} / \mathrm{ml}$ antibody solution in carbonate buffer, $\mathrm{pH} \mathrm{11}$, and was allowed to react for 2 hours. The solution was then run through a 100,000 MW cutoff Centricon centrifugal filter (Millipore, Billerica, MA) for $5 \mathrm{~min}$ at $4000 \mathrm{rpm}$ and washed twice with 
$200 \mu \mathrm{L}$ of water for $5 \mathrm{~min}$ at $4000 \mathrm{rpm}$ before being brought up to a final volume of 200 $\mu \mathrm{L}$ with water. Final protein concentrations were determined with a Pierce $\mathrm{GCA}^{\mathrm{TM}}$ protein assay kit (Pierce, Rockford, IL).

\section{Selective DNA and Protein Immobilization on Au electrode array}

A $50 \mu \mathrm{L}$ drop of $1 \mathrm{mM}$ 4-carboxyphenyl diazonium tetrafluoroborate, and $0.1 \mathrm{M}$ $\mathrm{Bu}_{4} \mathrm{NBF}_{4}$ in $\mathrm{ACN}$ was placed on the array covering all electrodes. 5 of the 9 working electrodes were held at $-1.0 \mathrm{~V}$ vs. $\mathrm{Ag} / \mathrm{AgNO}_{3}$ via a chronoamperometric step for 2 minutes each. Afterwards the array was rinsed with ACN, followed by ethanol, and sonicated for 10 seconds in ethanol. The array was again rinsed in ethanol, followed by water, and dried under a stream of nitrogen. The array was then treated with a $50 \mu \mathrm{L}$ drop (covering all electrodes) of $10 \mu \mathrm{M}$ DNA sequence 1, $10 \mathrm{mM}$ EDC, $1 \mathrm{mM}$ NHS, in

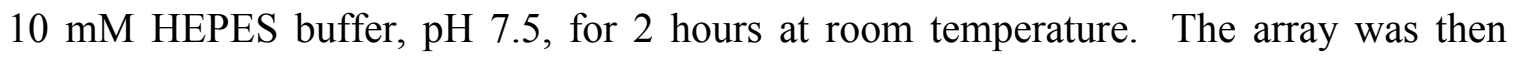
rinsed thoroughly in water and dried under a stream of nitrogen.

A $50 \mu \mathrm{L}$ drop of $40 \mu \mathrm{g} / \mathrm{mL}$ diazonium-modified anti-IL-12 capture antibody in $5 \mathrm{mM}$ $\mathrm{HCl}$ solution was placed on the array, covering all electrodes. 5 cyclic voltammograms were run on 4 of the 9 electrodes, not previously assembled with 4-carboxyphenyl diazonium, from 0 to $-900 \mathrm{mV}$ vs. $\mathrm{Ag} / \mathrm{AgCl}$, at $100 \mathrm{mV} / \mathrm{sec}$. The array was then washed with water and briefly dried under a stream of nitrogen.

\section{Simultaneous Detection of DNA and Protein}

Prepared DNA and antibody arrays were treated with a $50 \mu \mathrm{L}$ drop of one of three differing biological solutions: 1) $10 \mu \mathrm{M}$ DNA target sequence 2, with $400 \mathrm{ppb}$ control protein IL-1 $\beta$; 2) $10 \mu \mathrm{M}$ DNA control sequence 4, with 400 ppb target protein IL-12; 3) 10 mM DNA target sequence 2, with 400 ppb target protein IL-12, all in 2x SSC solution, $\mathrm{pH} 7.0$, for 2 hours at room temperature. The drop covered all electrodes on the array. After treatment, the array was consecutively rinsed 3 times each with: 1x SSC solution + $0.1 \%$ Tween-20, $1 \mathrm{x}$ SSC solution, and $0.1 \mathrm{x}$ SSC. This was followed by a brief rinse in water and the array was briefly dried under a stream of nitrogen.

Arrays were next treated with a $50 \mu \mathrm{L}$ drop of $10 \mu \mathrm{M}$ biotinlyated DNA sequence 3 and $1 \mathrm{ppm}$ biotinlyated anti-IL-12 detection antibody in $2 \mathrm{x}$ SSC solution, $\mathrm{pH} 7.0$, for 1 
hour at room temperature. The drop covered all electrodes on the array. After treatment, the array was consecutively rinsed 3 times each with: 1x SSC solution $+0.1 \%$ Tween-20, 1x SSC solution, and 0.1x SSC. This was followed by a brief rinse in water and the array was briefly dried under a stream of nitrogen. The arrays were then incubated with a 1:1000 dilution of ExtrAvidin-HRP in peroxidase stabilizer solution for 45 minutes. Afterwards the arrays were rinsed 3 times with $1 \mathrm{x}$ PBS, pH $7.4+0.1 \%$ Tween 20, followed by 3 rinses with 1x PBS, pH 7.4. Finally, the array was briefly rinsed in water and briefly dried under a stream of nitrogen. For detection, a $50 \mu$ drop of TMB conductivity solution was placed onto the array and the chronoamperometric current was measured at $0 \mathrm{~V}$ vs. $\mathrm{Ag} / \mathrm{AgCl}$. The current measured at each electrode 3 seconds after the potential step was collected and is reported as the current response.

\section{Optimization of DNA Immobilization and Hybridization}

A $50 \mu \mathrm{L}$ drop of $1 \mathrm{mM}$ 4-carboxyphenyl diazonium tetrafluoroborate, and $0.1 \mathrm{M}$ $\mathrm{Bu}_{4} \mathrm{NBF}_{4}$ in $\mathrm{ACN}$ was placed on the array covering all electrodes. Carboxylphenyl electrodeposition occurred via 5 differing protocols: 1) $30 \mathrm{sec}$ chronoamperometric step (CA) to $-1.0 \mathrm{~V}$ vs. $\left.\mathrm{Ag} / \mathrm{AgNO}_{3}, 2\right) 1$ min CA step to $\left.-1.0 \mathrm{~V}, 3\right) 2$ min CA step to $-1.0 \mathrm{~V}, 4$ ) $1 \mathrm{CV}$ from 0 to $-1.0 \mathrm{~V}, 5) 2 \mathrm{CVs}$ from 01 to $-1.0 \mathrm{~V}$. Afterwards the array was rinsed with ACN, followed by ethanol, and sonicated for 10 seconds in ethanol. The array was again rinsed in ethanol, followed by water, and dried under a stream of nitrogen. The array was then treated with a $50 \mu \mathrm{L}$ drop (covering all electrodes) of $10 \mu \mathrm{M}$ DNA sequence 1, 10

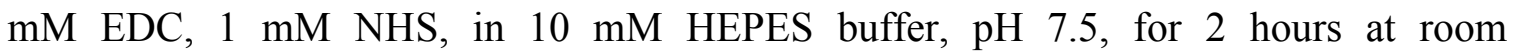
temperature. The array was then rinsed thoroughly in water and dried under a stream of nitrogen. The array was then treated with $10 \mu \mathrm{M}$ target DNA sequence 2 in $2 \mathrm{x}$ SSC, followed by treatment with $10 \mu \mathrm{M}$ biotinlyated DNA sequence 3, and finally ExtrAvidinHRP as described above in the Simultaneous DNA and Protein Detection section except that cytokine and detection antibody were not present. Controls for each electrodeposition protocol were formed as described above except that a random DNA control sequence 4 , was used instead of the target sequence 2. 
A calibration curve corresponding to the target DNA sequence 2 concentration from electrodes prepared from a 2 min CA electrodeposition of caboxyphenyl diazonium was obtained for this system and is shown below in Figure S1.

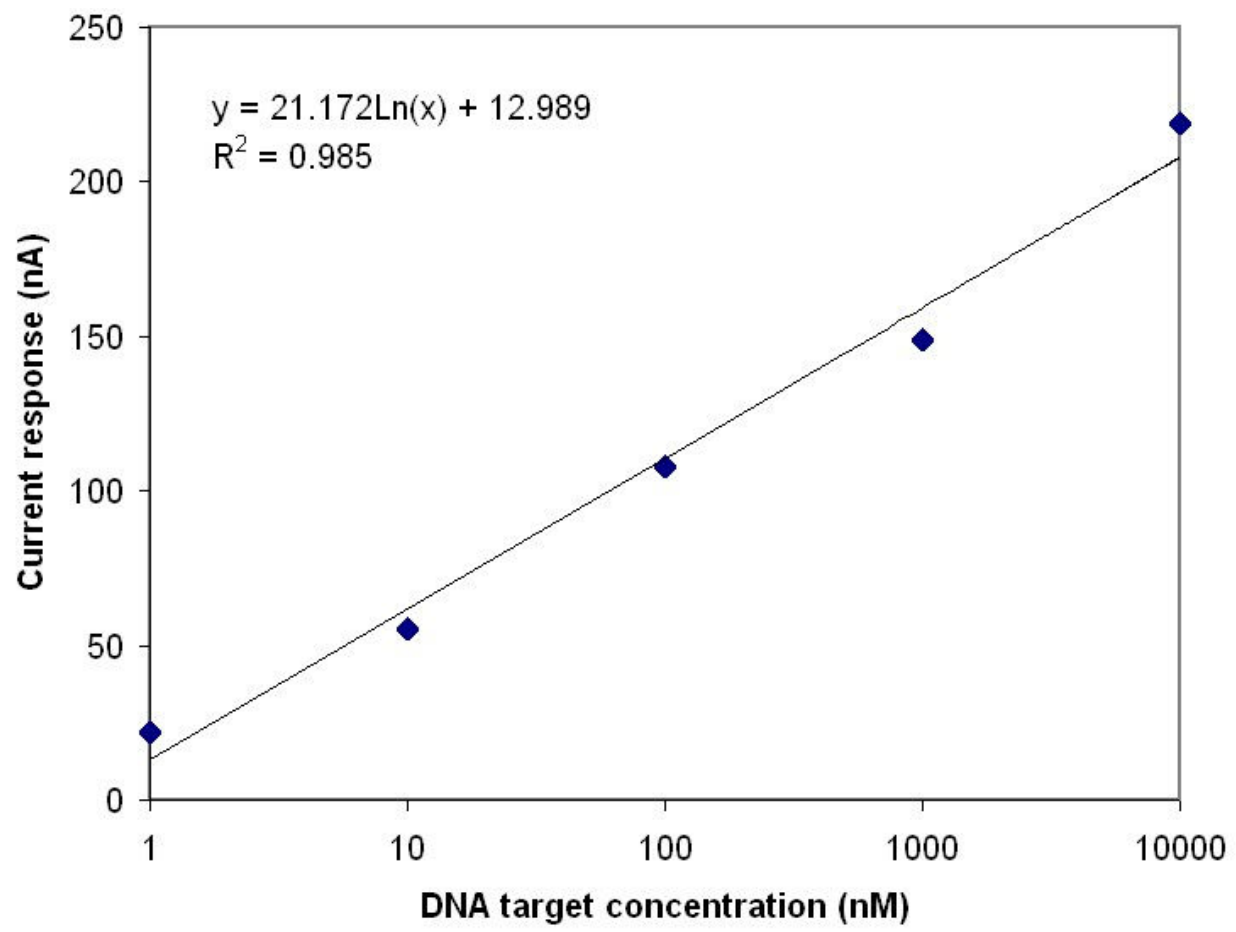

Figure S1. Calibration curve corresponding to DNA sequence 2 concentration. Measurements obtained in TMB conductivity solution 3 seconds after CA step to $0 \mathrm{~V}$ vs. $\mathrm{Ag} / \mathrm{AgCl}$.

Optimization of diazonium-antibody conjugate electrodeposition on gold electrodes has been reported previously. ${ }^{2}$

\section{References}

1. H, McNab; L. C. Monahan, J. Chem. Soc. Perkin Trans. 1: Org. and Bio-Org. Chem. 1989, 3, 419-424.

2. R. Polsky, J. C. Harper, D. R. Wheeler, S. M. Dirk, D. C. Arango, S. M. Brozik, submitted. 